\title{
Questões atuais relativas à dosagem e à descrição da excreção urinária de albumina
}

\section{Current issues in measurement and report of urinary albumin excretion}

\author{
W. Greg Miller'; David E. Bruns'; Glen L. Hortin33, Sverre Sandberg'; Kristin M. Aakre4; Matthew J. McQueen ${ }^{5}$; Yoshihisa Itoh ; \\ John C. Lieske7; David W. Seccombe ${ }^{8}$; Graham Jones ${ }^{9}$; David M. Bunk ${ }^{10}$; Gary C. Curhann ${ }^{11}$; Andrew S. Narva ${ }^{12}$; \\ on behalf of the National Kidney Disease Education Program - IFCC Working Group on Standardization of Albumin in Urine
}

\section{resumo}

Antecedentes: A excreção urinária de albumina indica lesão nos rins e é reconhecida como fator de risco para a progressão das doenças renal e cardiovascular. A dosagem da albumina urinária chama a atenção sobre a necessidade clínica de relatos de resultados precisos e claramente descritos. O National Kidney Disease Education Program e a Federação Internacional de Química Clínica e Medicina Laboratorial (IFCC) reuniram-se para avaliar o estado atual das questões pré-analíticas, analíticas e pós-analíticas que afetam as dosagens da albumina na urina e para identificar as áreas que necessitam de melhorias. Conteúdo: A química da albumina na urina não é completamente compreendida. Diretrizes atuais recomendam a utilização da relação albumina/creatinina (RAC) como substituta para a coleta de amostras cronometradas de urina, frequentemente inadequadas. Os resultados da RAC são afetados pela preparação do paciente, pela hora do dia da coleta das amostras e não é padronizada. Foram relatadas consideráveis diferenças intermétodos para a dosagem tanto de albumina quanto de creatinina, mas a verdade é desconhecida, porque não existem procedimentos de referência para a dosagem de albumina e não há materiais de referência para qualquer um desses analitos na urina. Os intervalos de referência recomendados para a RAC não consideram as grandes diferenças intergrupos na excreção da creatinina (por exemplo, relacionadas com diferenças em idade, sexo e etnia), nem o aumento contínuo no risco relacionado com a excreção de albumina. Discussão: Necessidades clínicas foram identificadas para a padronização de (a) métodos de coleta da urina, (b) dosagens de albumina e de creatinina na urina com base em um sistema de referência completo, (c) relatórios dos resultados dos testes e (d) intervalos de referência para a RAC. progression of kidney disease and cardiovascular disease. The role of urinary albumin measurements has focused attention on the clinical need for accurate and clearly reported results. The National Kidney Disease Education Program and the IFCC convened a conference to assess the current state of preanalytical, analytical, and postanalytical issues affecting urine albumin measurements and to identify areas needing improvement. Content: The chemistry of albumin in urine is incompletely understood. Current guidelines recommend the use of the albumin/creatinine ratio $(A C R)$ as a surrogate for the error-prone collection of timed urine samples. Although $A C R$ results are affected by patient preparation and time of day of sample collection, neither is standardized. Considerable intermethod differences have been reported for both albumin and creatinine measurement, but trueness is unknown because there are no reference measurement procedures for albumin and no reference materials for either analyte in urine. The recommended reference intervals for the ACR do not take into account the large intergroup differences in creatinine excretion (e.g., related to differences in age, sex, and ethnicity) nor the continuous increase in risk related to albumin excretion. Discussion: Clinical needs have been identified for standardization of (a) urine collection methods, (b) urine albumin and creatinine measurements based on a complete reference system, $(c)$ reporting of test results, and (d) reference intervals for the ACR.

\footnotetext{
1. Department of Pathology, Virginia Commonwealth University, Richmond, VA.

2. Department of Pathology, University of Virginia Medical School, Charlottesville, VA.

3. Department of Laboratory Medicine, Warren Magnuson Clinical Center, National Institutes of Health, Bethesda, MD.

4. Laboratory of Clinical Biochemistry, Haukeland University Hospital and The Norwegian Quality Improvement of Laboratory Services in Primary Care (NOKLUS), Bergen Norway.

5. Hamilton Regional Laboratory Medicine Program, Department of Pathology and Molecular Medicine, McMaster University, Hamilton, Ontario, Canada.

6. Department of Laboratory Medicine, Asahikawa Medical College, Asahikawa, Japan.

7. Mayo Clinic Renal Function Laboratory, Department of Laboratory Medicine and Pathology, Mayo Clinic Division of Nephrology and Hypertension, Department of Internal Medicine, Rochester, MN.

8. Canadian External Quality Assessment Laboratory and Department of Pathology and Laboratory Medicine, University of British Columbia, Vancouver, BC, Canada.

9. Department of Chemical Pathology, St Vincent's Hospital Sydney, Sydney, Australia.

10. Analytical Chemistry Division, National Institute of Standards and Technology, Caithersburg, MD.

11. Renal Division, Department of Medicine, Brigham and Women's Hospital, Harvard Medical School, Boston, MA.

12. National Kidney Disease Education Program, National Institute for Diabetes and Digestive Diseases, National Institutes of Health, Bethesda, MD.
} 


\section{Antecedentes}

Dosagens de albumina na urina são amplamente utilizadas para identificar e acompanhar pacientes com lesões nos rins. Uma conferência sobre uso clínico e dosagem de albumina na urina foi organizada pelo Laboratory Working Group of the National Kidney Disease Education Program e pela Federação Internacional de Química Clínica e Medicina Laboratorial (IFCC) para analisar as práticas atuais de dosagem de albumina na urina e utilizar os dados obtidos para acompanhamento da doença renal. Os objetivos da conferência foram aumentar a compreensão das questões que devem ser abordadas para permitir a padronização das dosagens e das diretrizes da prática clínica com base na excreção urinária de albumina. Este estudo resume as observações e conclusões dessa conferência.

Historicamente, a albuminúria foi definida em períodos de excreção urinária de albumina por unidade de tempo, normalmente 24 horas. A dificuldade de coletar amostra de urina de $24 \mathrm{~h}$ levou à substituição pela dosagem de taxa de excreção de albumina (TEA). Uma substituta comumente utilizada é a relação entre as concentrações urinárias de albumina e creatinina ${ }^{(71)}$. Essas duas opções de dosagens são consideradas neste estudo. Para a relação albumina/ creatinina (RAC), amostras aleatórias ou isoladas de urina foram coletadas sem se considerar a hora do dia, sendo citado um intervalo de referência comum tanto para homens quanto para mulheres. A hora do dia afeta os resultados, assim como a maior excreção de creatinina em homens do que em mulheres também afeta o uso da RAC como um substituto da TEA ${ }^{(71)}$. Da mesma forma, a maior excreção de creatinina em negros do que em brancos, a diminuição da excreção com a perda muscular e os efeitos da dieta sobre a excreção de creatinina.

\section{Pesquisa de diretrizes no uso de albumina urinária}

Organizações profissionais de vários países emitiram diretrizes de práticas clínicas para o uso de dosagens de albumina na urina. Essas diretrizes não são uniformes nas recomendações relativas a tipo de amostra, tempo de coleta da amostra, unidades, intervalos de referência ou pontos de corte utilizados para a interpretação, nem métodos utilizados para a dosagem de albumina e de creatinina.

A Tabela 1 enumera 10 diretrizes, recomendações e declarações emitidas por sete organizações desde 2002; cinco diretrizes estão relacionadas com diabetes e reco- mendam testes anuais. As 10 recomendam o uso da RAC, oito sugerem coleta da primeira urina da manhã, sete recomendam coleta de amostra aleatória ou isolada de urina e quatro identificam miligramas por grama ou miligramas por milimole como as unidades de medida para RAC ( $1 \mathrm{mg} / \mathrm{g}=1 \mu \mathrm{g} / \mathrm{mg}=0,113 \mathrm{mg} / \mathrm{mmol})$. Sete mencionam, com diferentes níveis de detalhe, a necessidade de realizar testes de seguimento para confirmar os resultados. Duas declararam, expressamente, que a coleta da urina de $24 \mathrm{~h}$ não é necessária, mas uma diretriz lista a coleta de $24 \mathrm{~h}$ como o primeiro dos três métodos possíveis de coleta de urina.

Embora a dosagem da RAC seja recomendada, a ausência de métodos reconhecidamente padronizados de coleta de amostras, de dosagem da RAC e de liberação de resultados compromete a utilidade deste teste tanto para a clínica quanto para a pesquisa. Os resultados descritos podem ser em miligramas de albumina por grama (ou $\mu \mathrm{g} / \mathrm{mg}$ ) ou por milimole de creatinina, e o significado de ambos não é intuitivamente óbvio para não especialistas. Prestadores de saúde podem não compreender o significado clínico da albuminúria e ter dificuldade em interpretar os resultados de forma efetiva (por exemplo, identificar os resultados que indicam um risco aumentado de doença cardiovascular ou progressão da doença renal). Os prestadores podem se confundir com tantas opções de teste para o rim e ficar preocupados que um único ponto de corte, como o tão citado $30 \mathrm{mg} / \mathrm{g}(30 \mu \mathrm{g} / \mathrm{mg}$, $3,4 \mathrm{mg} / \mathrm{mmol}$, ou $3,4 \mathrm{~g} / \mathrm{mol}$ ), pode não ser útil para pacientes de todas as idades, sexo e etnias ${ }^{(70,71)}$. Além disso, a relação entre a excreção de albumina na urina e o aumento de risco cardiovascular ou renal é contínuo, e considerar que todos os valores da RAC abaixo de $30 \mathrm{mg} / \mathrm{g}$ são normais, provavelmente, é inadequado ${ }^{(71)}$.

\section{Variáveis pré-analíticas que afetam a taxa de excreção de albumina}

A Tabela 2 relaciona importantes fatores pré-analíticos que podem influenciar a excreção de albumina na urina.

\section{Variação biológica intraindivíduo}

O conhecimento sobre a variação biológica intraindivíduo é importante para a tomada de decisões sobre quais tipos de amostras devem ser utilizados para a dosagem de albumina na urina, para interpretar um resultado de exame de confirmação após resultado inicial de aumento da concentração e para decidir se a variação na excreção de albumina é de importância clínica ou não. 
Tabela 1 Resumo das recomendações para a prática clínica de dosagem de albumina na urina*

\begin{tabular}{|c|c|c|c|}
\hline Autor/organização & $\begin{array}{l}\text { Recomendações de triagem, incluindo frequência, } \\
\text { coleta de amostras, métodos de análise }\end{array}$ & $\begin{array}{l}\text { Recomendações } \\
\text { de laudo }\end{array}$ & Referência \\
\hline $\begin{array}{l}\text { American Diabetes } \\
\text { Association** }^{* *}\end{array}$ & $\begin{array}{l}\text { Triagem: realize teste anual para a presença de } \\
\text { albumina na urina em pacientes com diabetes tipo } \\
1 \text { há mais de cinco anos e em todos os pacientes } \\
\text { diabéticos tipo 2, com início no momento do } \\
\text { diagnóstico e durante a gravidez. } \\
\text { Métodos: (a) Dosagem da RAC em amostra aleatória } \\
\text { (método preferido), (b) coleta de } 24 \text { h, permitindo } \\
\text { dosagem simultânea da depuração de creatinina e (c) } \\
\text { coleta cronometrada (por ex., } 4 \text { h ou durante a noite) }\end{array}$ & $\begin{array}{l}\text { Não diretamente } \\
\text { declarado, mas a tabela } \\
\text { mostrando os critérios } \\
\text { para os diferentes } \\
\text { diagnósticos utiliza } \\
\text { mg/g }\end{array}$ & (2) \\
\hline $\begin{array}{l}\text { Federação } \\
\text { Internacional de } \\
\text { Diabetes }\end{array}$ & $\begin{array}{l}\text { Cuidados padrão: verificar, anualmente, com tiras } \\
\text { reagentes, a proteinúria na amostra de urina da } \\
\text { manhã (ou amostra aleatória). Recomendada a } \\
\text { repetição/confirmação dos testes, incluindo RAC ou } \\
\text { RPCc. } \\
\text { Cuidados abrangentes: Avaliação da albuminúria por } \\
\text { método laboratorial quantitativo (RAC). } \\
\text { Cuidados mínimos: verificar, anualmente, com tiras } \\
\text { reagentes ou ácido sulfossalicílico para proteinúria } \\
\text { na urina da manhã (ou outra amostra aleatória). } \\
\text { Recomendada a repetição/confirmação dos testes, } \\
\text { incluindo RPC }\end{array}$ & $\begin{array}{l}\text { Não diretamente } \\
\text { declarado, mas a seção } \\
\text { de padrões de cuidados } \\
\text { médicos menciona } \\
\mathrm{mg} / \mathrm{mmol} \text { e } \mathrm{mg} / \mathrm{g}\end{array}$ & (3) \\
\hline $\begin{array}{l}\text { Kidney Disease: } \\
\text { Improving Global } \\
\text { Outcomes }\end{array}$ & $\begin{array}{l}\text { Proteína preferencial: a albumina é a proteína } \\
\text { urinária de preferência. } \\
\text { Dosagem: procedimentos de dosagem de albumina } \\
\text { devem ser controlados pelo material de referência } \\
\text { CRM 470. Múltiplos métodos disponíveis. Se } \\
\text { necessário, testes com base em anticorpos podem ser } \\
\text { utilizados; teste com tiras reagentes convencionais } \\
\text { em urina isolada é aceitável se for a única } \\
\text { opção disponível. São recomendadas repetições/ } \\
\text { confirmação dos testes. } \\
\text { Coleta/amostra: amostras aleatórias não } \\
\text { cronometradas de urina isolada são apropriadas } \\
\text { para o teste inicial. A primeira urina da manhã é } \\
\text { preferível, mas não exigida se há inconvenientes } \\
\text { substanciais em comparação com a amostra } \\
\text { aleatória. Coleta de urina cronometrada para a } \\
\text { albumina e creatinina pode ser efetuada se for } \\
\text { exigida redução na variabilidade }\end{array}$ & $\mathrm{mg} / \mathrm{g}$ & (4) \\
\hline
\end{tabular}


\begin{tabular}{lll}
\hline Tabela 1 & Resumo das recomendações para a prática clínica de dosagem de albumina na urina* (cont.) \\
\hline
\end{tabular}

\begin{tabular}{|c|c|c|c|}
\hline Autor/organização & $\begin{array}{l}\text { Recomendações de triagem, incluindo frequência, } \\
\text { coleta de amostras, métodos de análise }\end{array}$ & $\begin{array}{l}\text { Recomendações } \\
\text { de laudo }\end{array}$ & Referência \\
\hline $\begin{array}{l}\text { National Kidney } \\
\text { Foundation (US) }\end{array}$ & $\begin{array}{l}\text { Diretrizes para adultos e crianças: na maioria } \\
\text { das circunstâncias, amostras não cronometradas } \\
\text { de urina isolada devem ser usadas para detectar } \\
\text { e monitorar proteinúria em crianças e adultos. } \\
\text { Normalmente, não é necessária a coleta de urina } \\
\text { cronometrada (noturna ou } 24 \text { h) para avaliações. } \\
\text { Primeira amostra da manhã é preferível. Na maioria } \\
\text { dos casos, a triagem com tiras reagentes é aceitável } \\
\text { para detectar proteinúria. } \\
\text { Tiras reagentes comuns são aceitáveis para } \\
\text { detectar aumento de proteínas totais na urina. Tiras } \\
\text { reagentes específicas de albumina são aceitáveis } \\
\text { para detectar albuminúria. São recomendadas } \\
\text { repetições/confirmação dos testes, incluindo a RPC } \\
\text { ou RAC } \\
\text { Diretrizes específicas para os adultos: para a triagem } \\
\text { de adultos com risco aumentado de DRC, a albumina } \\
\text { deve ser dosada em amostra de urina isolada, } \\
\text { quer por meio de tiras reagentes específicas para } \\
\text { albumina, quer RAC. } \\
\text { Diretrizes para pacientes diabéticos: os pacientes } \\
\text { com diabetes devem ser rastreados anualmente para } \\
\text { DRC. Triagem inicial deve começar cinco anos após } \\
\text { o diagnóstico de diabetes tipo } 1 \text { ou no momento } \\
\text { do diagnóstico no tipo } 2 \text {. A triagem deve incluir } \\
\text { dosagens de RAC urinária em amostra isolada. São } \\
\text { recomendadas repetições/confirmação dos testes }\end{array}$ & $\begin{array}{l}\text { Recomendação } \\
\text { de unidades não } \\
\text { identificada }\end{array}$ & (5) \\
\hline $\begin{array}{l}\text { Caring for } \\
\text { Australians with } \\
\text { Renal Impairment }\end{array}$ & $\begin{array}{l}\text { Testes para proteinúria: para populações de alto } \\
\text { risco o teste inicial é RPC. Para pacientes com } \\
\text { diabetes e aborígenes e insulanos do Estreito } \\
\text { de Torres: o teste inicial é RAC. Recomendada a } \\
\text { repetição dos testes. } \\
\text { Método de avaliação: o método de escolha deve } \\
\text { ser moderado por considerações práticas, como } \\
\text { facilidade de uso, aceitabilidade pelo paciente e } \\
\text { custo. Para os testes iniciais para albuminúria, é } \\
\text { preferível a primeira urina da manhã, porém a RAC } \\
\text { aleatória é aceitável. São recomendadas repetições/ } \\
\text { confirmação dos testes; a RPC é identificada como } \\
\text { teste adequado para o diagnóstico de proteinúria } \\
\text { significativa }\end{array}$ & $\begin{array}{l}\text { Uma tabela dentro das } \\
\text { diretrizes utiliza g/dia, } \\
\mathrm{mg} / \mathrm{dl} \text { e } \mathrm{mg} / \mathrm{mmol} \text { para } \\
\text { os respectivos testes e } \\
\text { diagnósticos }\end{array}$ & (7) \\
\hline
\end{tabular}




\begin{tabular}{|c|c|c|c|}
\hline Autor/organização & $\begin{array}{l}\text { Recomendações de triagem, incluindo frequência, } \\
\text { coleta de amostras, métodos de análise }\end{array}$ & $\begin{array}{l}\text { Recomendações } \\
\text { de laudo }\end{array}$ & Referência \\
\hline $\begin{array}{l}\text { Joint Specialty } \\
\text { Committee on } \\
\text { Renal Medicine of } \\
\text { the Royal College } \\
\text { of Physicians of } \\
\text { London e da Renal } \\
\text { Association (UK) }\end{array}$ & $\begin{array}{l}\text { Método para detecção de albumina na urina: } \\
\text { albumina na urina deve ser dosada por método } \\
\text { laboratorial (quantitativo), com amostras de urina da } \\
\text { manhã (de preferência) ou de jato médio de urina } \\
\text { aleatória e expressa como RAC. Se forem utilizadas } \\
\text { tiras reagentes para detectar albumina urinária, os } \\
\text { testes positivos devem ter confirmação laboratorial. } \\
\text { Indicações para os ensaios: os pacientes com } \\
\text { diabetes que têm proteinúria persistente não } \\
\text { exigem teste de detecção de albumina na urina. } \\
\text { Todos os outros pacientes com diabetes devem } \\
\text { ser submetidos, no mínimo anualmente, a testes } \\
\text { de albuminúria. Atualmente, não há indicação de } \\
\text { triagem de albuminúria a pacientes que não têm } \\
\text { diabetes. } \\
\text { Método de detecção e quantificação de proteinúria: } \\
\text { não há necessidade de realizar coleta de urina de } \\
24 \text { h para a quantificação da proteinúria na atenção } \\
\text { primária. É recomendada a repetição/confirmação } \\
\text { dos testes, incluindo RAC ou RPC. } \\
\text { Indicações para o teste: exame com tira reagente } \\
\text { para proteína é indicado como parte da avaliação } \\
\text { inicial de pacientes com diagnóstico recente de } \\
\text { TFG < } 60 \text { ml/min/1,73 m², hematúria recentemente } \\
\text { descoberta e diversas outras condições. Não } \\
\text { recomendam a triagem com tira reagente para } \\
\text { quaisquer outros grupos }\end{array}$ & $\mathrm{mg} / \mathrm{mmol}$ & (8) \\
\hline $\begin{array}{l}\text { UK Renal } \\
\text { Association Clinical } \\
\text { Practice Guidelines: } \\
\text { Clinical Practice } \\
\text { Guidelines for the } \\
\text { Care of Patients } \\
\text { with Chronic Kidney } \\
\text { Disease }\end{array}$ & $\begin{array}{l}\text { Pacientes sob investigação ou em tratamento para } \\
\text { DRC, proteinúria detectada por tiras reagentes devem } \\
\text { ser avaliadas por meio da dosagem de RPC ou RAC, } \\
\text { idealmente, em primeira amostra de urina da manhã }\end{array}$ & $\begin{array}{l}\text { Não há recomendação } \\
\text { específica }\end{array}$ & (9) \\
\hline $\begin{array}{l}\text { National Institute for } \\
\text { Clinical Excellence } \\
\text { (UK) }\end{array}$ & $\begin{array}{l}\text { Cuidados renais para todas as pessoas com diabetes } \\
\text { tipo 2: dosagem da RAC ou da concentração } \\
\text { de albumina, anualmente. Utilize primeira } \\
\text { urina da manhã sempre que possível; utilize } \\
\text { teste de laboratório ou teste laboratorial remoto } \\
\text { especificamente para microalbuminuria. São } \\
\text { recomendadas repetições/confirmação dos testes }\end{array}$ & $\mathrm{mg} / \mathrm{mmol}$ & (10) \\
\hline
\end{tabular}




\section{Tabela 1 Resumo das recomendações para a prática clínica de dosagem de albumina na urina* (cont.)}

\begin{tabular}{l|l|l|l}
\hline Autor/organização & $\begin{array}{l}\text { Recomendações de triagem, incluindo frequência, } \\
\text { coleta de amostras, métodos de análise }\end{array}$ & $\begin{array}{l}\text { Recomendações } \\
\text { de laudo }\end{array}$ & Referência \\
$\begin{array}{l}\text { National Kidney } \\
\text { Foundation (US) }\end{array}$ & $\begin{array}{l}\text { Diretriz 2: avaliação de pacientes com DRC ou } \\
\text { hipertensão: RAC ou RPC em primeira urina da manhã } \\
\text { ou amostra aleatória isolada não cronometrada }\end{array}$ & (11) \\
\hline
\end{tabular}

*Usamos PubMed para localizar as diretrizes clínicas publicadas ou recomendações que incluíssem dosagem de proteína na urina como parte da avaliação de doença renal ou como um fator de risco para doença cardiovascular. As pesquisas incluíram combinações dos termos albumina na urina, proteínas na urina, diretrizes, dosagem, doença renal e detecção. Foi também utilizado como fonte o website The Kidney Diesease Improving Global Outcomes, que inclui diretrizes para a prática clínica com base em diversas organizações (http://www.kdigo.org/clinical_pratice_guidelines/index.php; acesso novembro 2008). ${ }^{*}$ Recomendações semelhantes são encontradas nas respectivas diretrizes da National Academy of Clinical Biochemistry, que foram desenvolvidas em conjunto com a American Diabetes Association (http://www.aacc.org/members/nacb/LMPG/Pages/default.aspx; acesso novembro 2008). RPC: relação proteína/creatinina; DRC: doença renal crônica; TFG: taxa de filtração glomerular.

\section{Tabela 2 Fatores pré-analíticos que afetam a excreção de albumina na urina*}

\begin{tabular}{l|c|l|c}
\hline Exercício & $\begin{array}{l}\text { Efeito sobre a excreção de } \\
\text { albumina urinária }\end{array}$ & $\begin{array}{l}\text { Consequências para o exame de albumina na } \\
\text { urina } \\
\text { Não deve ser realizado após exercício físico } \\
\text { intenso (a evidência não é totalmente } \\
\text { congruente) }\end{array}$ & $\begin{array}{c}\text { Referências } \\
\text { Febre }\end{array}$ \\
\hline $\begin{array}{l}\text { Bacteriúria } \\
\text { assintomática }\end{array}$ & Aumentado & $\begin{array}{l}\text { Não deve ser realizado até três dias após } \\
\text { febre }\end{array}$ & $(23-25)$ \\
\hline Postura (ortostática) & Aumentado & $\begin{array}{l}\text { Não é necessário triagem para bacteriúria } \\
\text { assintomática }\end{array}$ & $\begin{array}{l}\text { Um exame com resultado de excreção } \\
\text { elevada de albumina na urina em um jovem } \\
\text { ou adolescente deve ser repetido por exame } \\
\text { de amostra da primeira urina manhã }\end{array}$ \\
\hline
\end{tabular}

*As conclusões são baseadas em pesquisas PubMed usando as expressões "albumina na urina" ou "microalbuminúricos" ou "microalbumina" em combinação com "exercício" ou "febre" ou "bacteriúria" ou "infecção do trato urinário", respectivamente. "Proteinúria" foi usado em combinação com "ortostática" ou "postura". Para todas as pesquisas foram revisados "artigos relacionados" e a lista de referência dos artigos foi revista.

A Tabela S1 (no complemento de dados que acompanha a versão on-line deste artigo em http://www.clinchem.org/ content/vol55/issue1) mostra as estimativas de variabilidade biológica intraindivíduo (CVi) para excreção de albumina de $4 \%-103 \%$, com o tercil central de $28 \%-47 \%$. Fatores que influenciaram a diversidade nas estimativas incluem o período de coleta das amostras (dias, semanas, meses), o tipo de amostra de urina utilizada $(24 \mathrm{~h}$, cronometrada durante a noite, primeira da manhã, aleatória), o objetivo do estudo, a concentração de albumina na urina, o estado de saúde dos indivíduos e o manuseio e armazenamento pré-analítico das amostras de urina. A maioria dos estudos não descreve, em detalhe suficiente, o modo como a CVi foi calculada, para permitir a compreensão das diferenças.

No entanto, algumas conclusões gerais podem ser extraídas da Tabela S1. A CVi da RAC tinha o menor valor em 22 dos 30 estudos (73\%), para os quais a CVi de excreção de 24 h, as taxas de excreção durante a noite ou as concentrações foram comparadas com a CVi da RAC. A CVi da RAC para a variação do dia a dia nas amostras predominantemente noturnas cronometradas e da manhã é, em geral, inferior à RAC dos intervalos semana a semana ou mês a mês. No entanto, a variação da CVi de diferentes estudos é grande e, provavelmente, devida a diferenças nos 
métodos utilizados (por exemplo, fatores pré-analíticos, como armazenamento de amostras antes da análise) e fatores relacionados com os cálculos da CVi (como exclusão de outliers e teste de homogeneidade das variâncias). A omissão destes dois últimos fatores tende a aumentar a CVi relatada. Curiosamente, a CVi para a RAC ou concentração de albumina não foi cuidadosamente examinada nas amostras aleatórias de urina, mas existem estudos indicando maior CVi nestes $\operatorname{casos}^{(122,125)}$ (S1 e S14 no suplemento de dados on-line). A segunda urina da manhã demonstrou ser comparável à amostra de $24 \mathrm{~h}^{(50)}$, e dois estudos citados na Tabela S1 no suplemento de dados on-line, que utilizou segundas amostras da manhã, forneceram valores de CVi comparáveis aos de outros estudos que utilizaram primeiras amostras da manhã. No entanto, não foi realizada nenhuma comparação direta entre as primeiras e as segundas amostras manhã no mesmo estudo.

\section{Variação da albumina da urina durante a coleta e 0 armazenamento}

Em baixas concentrações de albumina na urina, a adsorção sobre a superfície dos recipientes de armazenamento pode levar a perdas significativas. A adesão de uma monocamada de albumina para uma superfície requer, aproximadamente, $0,15 \mu \mathrm{g} / \mathrm{cm}^{2(76)}$. A adsorção não específica de albumina urinária foi calculada em $<1 \mathrm{mg} / \mathrm{l}$ em superfícies hidrofílicas e $<2 \mathrm{mg} / \mathrm{l}$ em superfícies não hidrofílicas ${ }^{(44)}$. A adesão a superfícies também resulta em desnaturação e, tanto a adsorção quanto a desnaturação podem ser reduzidas quando uma superfície hidrofílica adequada é usada ou um detergente não iônico é adicionado ${ }^{(22,82)}$. A albumina afigura-se relativamente estável na interface ar-líquido quando é gerada espuma por mistura rápida ${ }^{(68)}$.

Houve várias recomendações sobre o armazenamento de longo prazo e a estabilidade das amostras de urina para

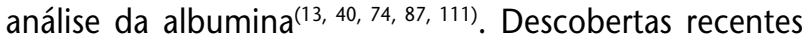
sugerem que as amostras de urina são estáveis por longos períodos quando congeladas a $-80^{\circ} \mathrm{C}$. Foram relatadas várias alterações na albumina quando armazenadas congeladas em temperaturas acima de $-80^{\circ} \mathrm{C}$, em particular

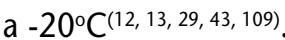

É preferível urina fresca, coletada em jato médio, para testes laboratoriais de rotina clínica. A albumina é, geralmente, estável na urina armazenada entre $2-8^{\circ} \mathrm{C}$ durante sete dias ${ }^{(50,87)}$. A influência de bactérias e proteases não foi bem estudada, mas ambas podem causar alterações na albumina da urina em algumas amostras.
Frequentemente, são formados precipitados na urina refrigerada ou congelada, e os seus efeitos sobre a dosagem de albumina não foram exaustivamente investigados. Os precipitados geralmente se dissolvem quando a urina é aquecida para análise. Foi relatado que o descongelamento da urina a $37^{\circ} \mathrm{C}$ minimiza o precipitado ${ }^{(114)}$, mas poderia aumentar a taxa de atividade de protease. Pode ser necessária centrifugação da urina turva para remover o material insolúvel antes da dosagem.

\section{Coleta de amostras de urina e realização dos testes}

Pesquisas da prática clínica têm mostrado grande variedade de coleta de amostras e de procedimentos de escolha para a dosagem e limiares de decisão utilizados. Um estudo de 2002 descreveu práticas de teste da albumina na urina em hospitais e consultórios médicos em Montana (EUA) e verificou que apenas $43 \%$ e $46 \%$, respectivamente, utilizaram limiares recomendados pela American Diabetes Association ou pela National Kidney Foundation (EUA) ${ }^{(45)}$. Em 2003, um estudo francês de clínica geral para cuidados de pacientes diabéticos relatou que apenas $36 \%$ dos pacientes tinham teste de albumina na urina e que apenas a coleta de urina de $24 \mathrm{~h}$ foi considerada adequada ${ }^{(31)}$. Uma pesquisa da British Pediatric Diabetes Care Practices relatou, em 2005, que o teste predominante foi a dosagem de RAC em amostras da manhã (81\%), enquanto coletas cronometradas noturnas e coletas de $24 \mathrm{~h}$ foram utilizadas por $14 \%$ e $5 \%$, respectivamente ${ }^{(28)}$.

Durante o ano de 2006, uma avaliação baseada em questionário de avaliação da albumina na urina na atenção primária de saúde foi realizada em nove países europeus, com respostas de 2.078 médicos generalistas ${ }^{(1)}$. Amostras aleatórias de urina prevaleceram para o primeiro exame de albumina na urina, enquanto coletas cronometradas foram utilizadas em larga escala para o teste de repetição, especialmente quando realizado em laboratório hospitalar. Apenas 45\%-77\% dos médicos generalistas solicitaram teste de repetição se o primeiro teste foi positivo. A prevalência de instrumentos para análise da albumina na urina no consultório variou de $4 \%$ a $88 \%$ entre os países, com maiores números na Noruega e Suécia e mais baixos na França. Quando instrumentos do consultório foram utilizados, as dosagens quantitativas de RAC prevaleceram na Escandinávia, enquanto tiras semiquantitativas de albumina estavam em utilização generalizada nos outros países. Em todos os países, exceto na Holanda, havia quatro diferentes formas de relatar resultados de albumina na urina: concentração $(\mathrm{mg} / \mathrm{l})$, 
excreção por $24 \mathrm{~h}(\mathrm{mg} / 24 \mathrm{~h})$, excreção por minuto ( $\mu \mathrm{g} / \mathrm{min})$ e RAC $(\mathrm{mg} / \mathrm{mmol}$ ou $\mathrm{mg} / \mathrm{g})$. Os médicos, na maioria dos países, estimaram que uma variação de $33 \%$ nos resultados da albumina na urina indicaria variação clínica significativa na condição do paciente, independente do tipo de amostra utilizado para a dosagem.

Em 2006, uma pesquisa da prática de 55 laboratórios na Austrália/Nova Zelândia mostrou grande variabilidade nos tipos de amostra e de coleta recomendados, incluindo a coleta da urina de $24 \mathrm{~h}$, ou amostras cronometradas, amostras aleatórias isoladas, bem como coleta da primeira urina da manhã ${ }^{(62)}$. O limiar de decisão relatado pelos laboratórios variou de 15 a $30 \mathrm{mg} / \mathrm{l}$ de albumina na urina e 1 a $3,6 \mathrm{mg} / \mathrm{mmol}(9-32 \mathrm{mg} / \mathrm{g})$ para a RAC. Não houve relação entre os intervalos de referência e o instrumento/ método utilizados.

\section{Formas moleculares da albumina na urina}

A quantidade e a forma molecular de albumina na urina podem diferir das do plasma devido ao diferencial de filtração ou à captação tubular de formas alteradas de albumina, à alteração da albumina por proteólise durante a passagem pelo trato urinário, à alteração química por oxidantes, radicais livres e outros ligantes concentrados na urina e a alterações durante o armazenamento da amostra.

\section{Estrutura da albumina}

Propriedades estruturais da albumina plasmática foram revistas por Peters ${ }^{(90)}$. O gene para a albumina do soro humano codifica um precursor, a pré-proalbumina, que é transformado, intracelularmente, na proteína plasmática madura de 585 resíduos de aminoácidos, secretada pelos hepatócitos. Polipeptídios da albumina não sofrem alterações pós-translacionais intracelularmente. Um alto conteúdo de aminoácidos ácidos contribui para uma carga líquida de -15 a -20 em pH neutro, ponto isoelétrico próximo de 5 e de alta solubilidade hídrica. A cristalografia de raios $X$ mostra uma proteína em forma de coração, com três domínios globulares formando um $\mathrm{V}^{(17,25)}$. A albumina é estabilizada por 17 ligações internas de dissulfeto cruzadas e um elevado teor de estrutura $\alpha$-helicoidal, resultando em uma molécula relativamente resistente à desnaturação ${ }^{(90)}$. A albumina, em solução, comporta-se hidrodinamicamente como um cilindro de $14 \mathrm{~nm}$ de comprimento. A forma alongada e o tamanho hidrodinâmico aumentado podem ser importantes para diminuir a filtração glomerular de albumina.
Alelos mutantes de albumina são expressos em $<1$ em 1.000 pessoas ${ }^{(90)}$, portanto deveriam afetar raramente a análise quantitativa de albumina. Algumas mutações pontuais, contudo, afetam a depuração renal de albumina ${ }^{(59)}$, produzindo diferentes proporções de albumina modificada na urina e no soro.

$\mathrm{O} \mathrm{pH}$ normal da urina ( $\mathrm{pH}$ 5-8) não afeta a forma da albumina. No pH abaixo de 4 e acima de 8 , a albumina sofre grandes mudanças estruturais, a maioria reversível(90). A concentração máxima de ureia na urina é de, aproximadamente, $1 \mathrm{~mol} / \mathrm{l}$ e não deve causar desnaturação ${ }^{(90)}$.

A albumina tem até seis sítios de ligação para ácidos graxos de cadeia longa por molécula. No plasma, normalmente há cerca de um de ácido graxo por molécula de albumina, mas essa proporção pode ser aumentada várias vezes com o estresse, o exercício ou a terapia com heparina. Quantidades variáveis de ácidos graxos ligados alteram a mobilidade eletroforética da albumina em eletroforese não desnaturante e focalização isoelétrica ${ }^{(38,75)}$.

A albumina é transportadora de numerosas moléculas

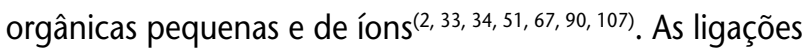
dessas moléculas podem afetar a conformação da albumina ${ }^{(2,35,90)}$. Outros compostos endógenos, como o cobre e a tiroxina, ligados à albumina ocupam $<1 \%$ das moléculas de albumina no plasma. A bilirrubina ocupa uma pequena porcentagem de moléculas de albumina, exceto nos estados hiperbilirrubinêmicos severos, nos quais mais de metade das moléculas de albumina podem ter bilirrubinas ligadas. Em concentrações fisiológicas no plasma, 1-2 íons cálcio e 7-8 íons cloreto estão ligados por molécula de albumina ${ }^{(33,34)}$. A ligação desses íons é dependente do $\mathrm{pH}$ e, portanto, variável na urina, e íons podem dissociar rapidamente ou trocar com outros íons durante a análise.

A urina é enriquecida em relação ao plasma por componentes peptídicos de baixo peso molecular e derivados aminoácidos, como ácido hipúrico e fenilacetilglutamina ${ }^{(52,84,109)}$. Em uma base molar, a concentração desses compostos na urina geralmente é superior à de albumina, então pode haver muitas ligações vinculadas à albumina ${ }^{(52,84)}$. No plasma, a albumina também liga uma gama diversificada de peptídeos para os quais existem dados limitados em relação a afinidade e estequiometria de ligação(72, 73).

A albumina contém dois sítios (Sudlow I e II) para a ligação de várias drogas e compostos endógenos ${ }^{(107)}$. Alguns desses compostos, como salicilatos, antibióticos, sulfa e penicilinas, ocorrem em concentrações elevadas na urina. 


\section{Formas covalentemente modificadas de albumina}

A albumina contém uma cisteína não pareada no resíduo 34. Ela tem um pK incomumente baixo de, aproximadamente, 5, que resulta em aumento da reatividade e das taxas de formação de ligações dissulfeto e de intercâmbio com outros compostos contendo sulfidrila no plasma ${ }^{(32,153,90)}$. A albumina pode formar dímeros de dissulfeto, com 2 monômeros de albumina ligados pelos resíduos cisteína-34, ou a cisteína da cadeia lateral pode ser oxidada em um ácido sulfônico ${ }^{(77,90)}$. A albumina, com várias alterações de cisteína-34, tem diferentes propriedades de ligação para uma variedade de ligantes, sugerindo uma variação estrutural significativaa ${ }^{(86,90)}$. Alguns dímeros de albumina, principalmente com ligações dissulfeto, são observados em amostras de urina ${ }^{(15,39,90,108,124,127)}$.

A albumina tem meia-vida longa, de cerca de 20 dias, na corrente sanguínea ${ }^{(21,90)}$, o que the permite acumular variações químicas. Reações com aminoácidos de cadeias colaterais resultam em grupo carbonil, carboximetilisina, produtos finais de glicação avançada em uma pequena proporção de moléculas de albumina ${ }^{(77,120,123)}$. Ligações cruzadas de ditirosina também são detectadas ${ }^{(86)}$. No plasma, 1\%-10\% das moléculas de albumina são glicados pela reação com a glicose, com elevadas concentrações em pessoas com diabetes ${ }^{(19,90)}$. A maior proporção de albumina glicada na urina em relação ao plasma foi atribuída à menor eficiência de absorção tubular da forma glicada ${ }^{(19)}$. A captação tubular de albumina é um processo mediado por receptor com grande especificidade ${ }^{(26,37)}$.

\section{Fragmentação de albumina}

Vários fragmentos albumina $>5 \mathrm{kDa}$ foram detectados

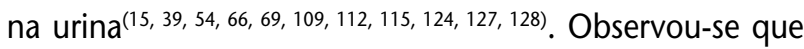
as proporções de fragmentos aumentam com doença renal ${ }^{(15,39,124,127)} \mathrm{e}$, possivelmente, com o armazenamento prolongado de amostras a $-20^{\circ} \mathrm{C}^{(109)}$. As sequências de vários fragmentos grandes foram identificadas na urina $\mathrm{e}$ alguns foram detectados no plasma, sugerindo que certos fragmentos na urina vieram do plasma ${ }^{(15)}$.

Fragmentos de albumina de 500-5.000 Da têm sido descritos no plasma e na urina ${ }^{(20,46,47,63-65,94,97,126)}$. Alguns se acumulam no plasma de pacientes com insuficiência renal. A filtração glomerular é um processo dependente de tamanho e carga, e pequenos fragmentos positivamente carregados gerados no plasma deveriam ser rapidamente removidos pelo rim saudável|(11,83).
Várias formas truncadas de albumina foram detectadas no plasma, com deleções de um ou dois aminoácidos $\mathrm{N}$-terminal( ${ }^{(10)}$ ou um, seis ou 13 aminoácidos $\mathrm{C}$-terminal(5,9). Albumina sem o resíduo leucina C-terminal representa 4\%-15\% da albumina do plasma normal(9), e esta pode vir a ser a principal forma de albumina no plasma e na urina de pacientes com doenças críticas $^{(5,9)}$.

Proteases ao longo do trato urinário e na urina podem gerar fragmentos de albumina ou novas alterações de fragmentos no sistema urinário e durante o armazenamento da amostra $^{(8,113,118)}$. Algumas albuminas do interior de células tubulares podem ser parcialmente digeridas e os fragmentos podem retornar à urina ${ }^{(99)}$.

\section{Influência das formas estruturais da albumina na urina para a dosagem}

O imunoensaio tem sido o principal método para a quantificação de albumina na urina. A albumina humana é altamente antigênica em muitas espécies animais ${ }^{(90)}$. A resposta policlonal de coelhos é dirigida contra, pelo menos, cinco sítios antigênicos diferentes ${ }^{(101)}$, sugerindo que os imunoensaios com antissoros policlonais podem reagir com muitas albuminas modificadas. A existência de vários sítios antigênicos é coerente com evidências de que um teste imunoturbidimétrico reage com a albumina clivada em três partes por brometo de cianogênio, com a albumina quimicamente modificada e com a albumina animal, que diferem na sequência de aminoácidos em mais de $20 \%$ da albumina humana ${ }^{(109)}$.

\section{Procedimentos de rotina para a dosagem de albumina na urina}

Concentrações de albumina urinária $<150 \mathrm{mg} / \mathrm{l}$ estão abaixo do limite de deteç̧ão do teste colorimétrico de tiras reagentes utilizado na rotina do exame de urina. Os imunoensaios disponíveis, incluindo turbidimétrico, nefelométrico e procedimentos imunométricos de dois sítios, normalmente têm limites de detecção de $2-10 \mathrm{mg} / \mathrm{l}^{(14,41)}$. Os formatos incluem: reagentes líquidos com dosagens nefelométricas quantitativas ou dosagens espectrofotométricas e tiras de fluxo lateral com determinação semiquantitativa visual. Métodos clínicos de rotina usam anticorpos tanto policlonais quanto monoclonais que podem influenciar a sensibilidade para dosar formas alteradas e fragmentos de albumina.

A cromatografia líquida de exclusão por tamanho foi aplicada como método alternativo e fornece valores 
superiores aos do imunoensaio para a maioria das amostras. Esta observação levou a uma hipótese polêmica de que a cromatografia de exclusão por tamanho detecta uma forma de albumina que não é detectada pelo imunoensaio ${ }^{(14,23,88,89)}$. Esta hipótese tem sido questionada com base na reatividade apresentada dos antissoros policlonais com múltiplos sítios antigênicos na albumina ${ }^{(101,108)}$. Além disso, os resultados do método de exclusão por tamanho incluem outras moléculas com, aproximadamente, o mesmo tamanho da albumina, incluindo diversas proteínas urinárias ${ }^{(108)}$.

\section{Desempenho dos procedimentos de dosagem de albumina na urina}

Não existem dados descritos sobre a uniformidade de resultados entre os métodos e entre os laboratórios que utilizam amostras recém-coletadas. Assim, nós examinamos a variação nos resultados entre laboratórios e entre métodos pelo Esquema de Avaliação Externa de Qualidade (EQAS). Em princípio, as amostras utilizadas em tais pesquisas deveriam refletir o conteúdo e a composição da albumina na urina original e ser permutáveis com a urina original. Na prática, as mostras de urina utilizadas nos EQAS são frequentemente preparadas com adição de albumina e creatinina purificadas, e podem incluir outros analitos, estabilizadores e aditivos para ajuste de $\mathrm{pH}$. Essas amostras podem ter uma matriz menos complexa e com moléculas de albumina mais homogêneas do que as encontradas na urina original e fornecer resultados de EQAS mais uniformes do que os de urina original.

A Tabela 3 mostra que diferentes organizadores de EQAS utilizam distintos materiais e os tratam de maneiras diferentes. As amostras que utilizam urina líquida original, com pouca ou nenhuma adição de albumina e creatinina purificadas, são mais suscetíveis de serem comparáveis. A experiência do Centro Norueguês para a Garantia de Qualidade em Atenção Primária à Saúde (NOKLUS) indica que as amostras de urina de pacientes com albuminúria se comportam de forma diferente em alguns métodos quando comparadas com a urina normal com adição de albumina humana purificada. Quanto mais sintética e mais processada a amostra, mais incerta será sua comparabilidade. As amostras que foram liofilizadas não são suscetíveis de serem comparáveis com as amostras originais. Amostras não comparáveis são limitadas para avaliar a concordância de resultados dentro de um método/instrumento de um mesmo grupo e não podem ser usadas para avaliar a concordância entre métodos diferentes.
A Tabela 4 apresenta exemplos de toda a gama de resultados observados em vários programas EQAS em diferentes países. Quando foi considerado que o material EQAS tinha uma probabilidade razoável de ser comparável, os dados de todos os participantes foram combinados para representar o desempenho agregado entre métodos e entre laboratórios. Quando o material era menos provável de ser comparável, os dados foram separados por métodos, para se obter uma estimativa de desempenho entre laboratórios, dentro do método. Todos os EQAS excluíram outliers (utilizando procedimentos diferentes) antes de calcularem as estatísticas. A variação \pm 2 SD foi calculada a partir dos dados disponíveis para fornecer uma estimativa de um intervalo central de $95 \%$ dos resultados relatados.

Todos os estudos demonstraram variabilidade entre os laboratórios e entre os procedimentos de dosagem (Tabela 4). A variação entre laboratórios dentro do método foi menor do que a variação combinada entre laboratórios e entre métodos, sugerindo que houve diferenças de calibração entre os métodos. É difícil avaliar se o atual desempenho analítico atende aos requisitos clínicos porque esses requisitos não foram definidos na base das evidências dos resultados. Caso uma especificação de qualidade para imprecisão da dosagem da concentração de albumina na urina seja metade da variação biológica intraindivíduo, e seja tomado um CVi típico de 40\% (Tabela S1 no complemento de dados on-line), os resultados EQAS podem preencher este critério. Os desvios não podem ser avaliados porque não existe sistema de referência em vigor.

\section{Sistema de referência para a dosagem de albumina urinária}

Um sistema de referência de albumina na urina requer material de referência (MR) tanto primário quanto secundário (matriz) e um procedimento de dosagem de referência (PDR) com o qual o valor atribuído de um MR possa ser, precisamente, transferido para uma amostra de paciente por meio da dosagem hierarquizada da cadeia de rastreabilidade ${ }^{(56)}$. Neste momento, o site do Joint Committee for Traceability in Laboratory Medicine (JCTLM) não relaciona uma ordem superior de MR ou PDR para albumina na urina ${ }^{(60)}$.

Um MR destinado à calibração de procedimentos de dosagem de rotina deve ser comparável com urina original para todos os procedimentos. Este atributo significa que os métodos de rotina terão reatividade imunoquímica equivalente em relação à(s) molécula(s) de albumina no MR tanto quanto da albumina na urina original. A comparabilidade 


\section{Resumo dos programas EQAS de vários países, mostrando os materiais utilizados para pesquisa de}

Tabela 3 albumina na urina

\begin{tabular}{|c|c|c|c|c|c|}
\hline $\begin{array}{l}\text { Programa } \\
\text { EQAS* }\end{array}$ & Tipo de amostra & $\begin{array}{l}\text { Condições durante } 0 \\
\text { preparo da amostra }\end{array}$ & $\begin{array}{l}\text { Condições antes } \\
\text { da distribuição aos } \\
\text { participantes }\end{array}$ & $\begin{array}{l}\text { Condições durante } \\
\text { a distribuição aos } \\
\text { participantes }\end{array}$ & $\begin{array}{c}\text { Prováveis } \\
\text { de ser } \\
\text { comparáveis** }\end{array}$ \\
\hline $\begin{array}{l}\text { EQUALIS } \\
\text { (Suécia) }\end{array}$ & Urina normal & $\begin{array}{l}\text { Adição de cloreto } \\
\text { de benzamidinium } \\
\text { à urina normal. } \\
\text { Congelados, } \\
\text { descongelados e } \\
\text { filtrados. Adição } \\
\text { de albumina e } \\
\text { recongelada a }-80^{\circ} \mathrm{C}\end{array}$ & $\begin{array}{l}\text { Descongelada, } \\
\text { diluída com } \mathrm{NaCl} \text { e } \\
\text { adição de creatinina }\end{array}$ & $\begin{array}{l}\text { Líquida à } \\
\text { temperatura } \\
\text { ambiente }\end{array}$ & Sim \\
\hline $\begin{array}{l}\text { Labquality } \\
\text { (Finlândia, } \\
\text { Noruega e } \\
\text { outros) }\end{array}$ & Urina normal & Urina fresca & $\begin{array}{l}\text { Suplementada } \\
\text { com albumina e } \\
\text { creatinina }\end{array}$ & $\begin{array}{l}\text { Líquida à } \\
\text { temperatura } \\
\text { ambiente }\end{array}$ & Sim \\
\hline $\begin{array}{l}\text { NOKLUS } \\
\text { (Noruega, } \\
\text { GPs) }\end{array}$ & $\begin{array}{l}\text { Urina de } \\
\text { pacientes com } \\
\text { albuminúria }\end{array}$ & Congeladas a $-80^{\circ} \mathrm{C}$ & $\begin{array}{l}\text { Descongelada e } \\
\text { filtrada estéril }\end{array}$ & $\begin{array}{l}\text { Líquida à } \\
\text { temperatura } \\
\text { ambiente }\end{array}$ & Sim \\
\hline $\begin{array}{l}\text { QMP-LS } \\
\text { (Ontario, } \\
\text { Canadá) }\end{array}$ & $\begin{array}{l}\text { De um único } \\
\text { paciente doador } \\
\text { com albuminúria }\end{array}$ & $\begin{array}{l}\text { Segunda amostra } \\
\text { de outro paciente } \\
\text { com albuminúria } \\
\text { pode ser adicionada } \\
\text { para ajustar a } \\
\text { concentração }\end{array}$ & Armazenada a $4^{\circ} \mathrm{C}$ & $\begin{array}{l}\text { Líquida e } \\
\text { expedida em } \\
\text { embalagem fria }\end{array}$ & Sim \\
\hline $\begin{array}{l}\text { Digital PT } \\
\text { (British } \\
\text { Columbia, } \\
\text { Canadá) }\end{array}$ & $\begin{array}{l}\text { Urina sintética } \\
\text { estabilizada (não } \\
\text { doador) }\end{array}$ & Líquida a $4^{\circ} \mathrm{C}$ & Líquida a $4^{\circ} \mathrm{C}$ & $\begin{array}{l}\text { Líquida e } \\
\text { expedida em } \\
\text { embalagem fria }\end{array}$ & Desconhecido \\
\hline CAP (EUA) & Urina normal & $\begin{array}{l}\text { Adicionados } \\
\text { albumina, creatinina, } \\
\text { outros analitos, } \\
\text { conservantes }\end{array}$ & Armazenada a $4^{\circ} \mathrm{C}$ & $\begin{array}{l}\text { Líquido e } \\
\text { expedida em } \\
\text { embalagem fria }\end{array}$ & Desconhecido \\
\hline $\begin{array}{l}\text { RCPA-QAP } \\
\text { (Austrália) }\end{array}$ & Urina normal & $\begin{array}{l}\text { Adicionadas } \\
\text { albumina, creatinina, } \\
\text { outras substâncias e } \\
\text { liofilizada }\end{array}$ & $\begin{array}{l}\text { Nada após } \\
\text { liofilização, } \\
\text { armazenada a } 4^{\circ} \mathrm{C}\end{array}$ & Liofilizada & Não \\
\hline
\end{tabular}

*EQUALIS (External Quality Assurance in Laboratory Medicine in Sweden): Garantia de Qualidade Externa em Medicina Laboratorial, na Suécia; NOKLUS (Norweigian Quality Improvement of Primary Care Laboratories): Melhoria da Qualidade da Atenção Básica de Laboratórios Noruegueses; GP (general practitioner): Médico Generalista; QMP-LS (Quality Management Programme, Laboratory Services): Programa de Gestão da Qualidade, Testes Laboratoriais; CAP (College of American Pathologists): Colégio Americano de Patologistas; RCPA-QAP (Royal College of Pathologists of Australasia Quality Assurance Programs): Colégio Real de Patologistas da Australásia - Programas de Garantia de Qualidade.

**A permutabilidade da urina natural fresca de pacientes com aumento da excreção de albumina é baseada em considerações teóricas da preparação de amostra EQAS; a permutabilidade não foi validada para nenhum material. 
Tabela 4 Variação dos resultados de albumina na urina observados nos estudos EQAS em diferentes países*

\begin{tabular}{|c|c|c|c|c|}
\hline $\begin{array}{l}\text { Programa } \\
\text { EQAS** }\end{array}$ & $n$ & $\begin{array}{l}\text { Mediana ou média } \\
\text { (mg/l) }\end{array}$ & $\begin{array}{l}\mathrm{CV} \\
(\%)\end{array}$ & $\begin{array}{l}\text { Variação } \\
\pm 2 S D\end{array}$ \\
\hline EQUALIS & 200 & 20 & 10,8 & $16-25$ \\
\hline EQUALIS & 200 & 31 & 8,2 & $26-37$ \\
\hline Labquality & 136 & 19 & 15,4 & $14-25$ \\
\hline Labquality & 136 & 76 & 8,9 & $63-89$ \\
\hline QMP-LS & 28 & 20 & 16,5 & $14-26$ \\
\hline QMP-LS & 29 & 22 & 10,9 & $17-26$ \\
\hline QMP-LS & 28 & 58 & 6,9 & $50-66$ \\
\hline $\begin{array}{l}\text { NOKLUS (consultório de } \\
\text { médicos generalistas) }\end{array}$ & 1012 & 35 & 12,1 & $27-44$ \\
\hline NOKLUS turbidimetria & 430 & 20 & 6,6 & $17-44$ \\
\hline NOKLUS turbidimetria & 424 & 68 & 5,2 & $61-74$ \\
\hline Digital PT & 38 & 36 & 11,3 & $28-44$ \\
\hline Digital PT & 37 & 74 & 8,4 & $61-86$ \\
\hline $\begin{array}{l}\text { Método CAP A, } \\
\text { turbidimetria }\end{array}$ & 262 & 25 & 10,4 & $20-27$ \\
\hline $\begin{array}{l}\text { Método CAP A, } \\
\text { turbidimetria }\end{array}$ & 207 & 87 & 5,1 & $79-92$ \\
\hline $\begin{array}{l}\text { Método CAP B, } \\
\text { turbidimetria }\end{array}$ & 203 & 27 & 6,9 & $23-29$ \\
\hline $\begin{array}{l}\text { Método CAP B, } \\
\text { turbidimetria }\end{array}$ & 194 & 83 & 3,1 & $78-85$ \\
\hline $\begin{array}{l}\text { Método CAP C, } \\
\text { turbidimetria }\end{array}$ & 162 & 30 & 7,1 & $26-32$ \\
\hline $\begin{array}{l}\text { Método CAP C, } \\
\text { turbidimetria }\end{array}$ & 123 & 88 & 4,5 & $80-92$ \\
\hline $\begin{array}{l}\text { Método CAP D, } \\
\text { turbidimetria }\end{array}$ & 118 & 26 & 5 & $24-28$ \\
\hline $\begin{array}{l}\text { Método CAP D, } \\
\text { turbidimetria }\end{array}$ & 86 & 84 & 3,8 & $78-87$ \\
\hline $\begin{array}{l}\text { Método CAP E, } \\
\text { turbidimetria }\end{array}$ & 76 & 24 & 6,2 & $21-25$ \\
\hline $\begin{array}{l}\text { Método CAP E, } \\
\text { turbidimetria }\end{array}$ & 112 & 87 & 4,9 & 78-91 \\
\hline $\begin{array}{l}\text { Método CAP F, } \\
\text { turbidimetria }\end{array}$ & 96 & 26 & 10,1 & $21-29$ \\
\hline $\begin{array}{l}\text { Método CAP F, } \\
\text { turbidimetria }\end{array}$ & 82 & 89 & 4,9 & $81-94$ \\
\hline $\begin{array}{l}\text { Método CAP G, } \\
\text { turbidimetria }\end{array}$ & 95 & 27 & 6,2 & $23-28$ \\
\hline $\begin{array}{l}\text { Método CAP G, } \\
\text { turbidimetria }\end{array}$ & 79 & 86 & 5,3 & $76-90$ \\
\hline
\end{tabular}




\section{Tabela 4 Variação dos resultados de albumina na urina observados nos estudos EQAS em diferentes países* (cont.)}

\begin{tabular}{ccccc}
\hline $\begin{array}{c}\text { Programa } \\
\text { EQAS** }\end{array}$ & $n$ & $\begin{array}{c}\text { Mediana ou média } \\
(\mathrm{mg} / \mathrm{l})\end{array}$ & $\begin{array}{c}\text { CV } \\
(\%)\end{array}$ & $\begin{array}{c}\text { Variação } \\
\pm 2 S \mathrm{D}\end{array}$ \\
$\begin{array}{c}\text { Método CAP H, } \\
\text { turbidimetria }\end{array}$ & 97 & 26 & 7 & $23-28$ \\
$\begin{array}{c}\text { Método CAP H, } \\
\text { turbidimetria } \\
\text { Método RCPA A, }\end{array}$ & 69 & 93 & 4,5 & $30-97$ \\
$\begin{array}{c}\text { turbidimetria } \\
\text { Método RCPA A, }\end{array}$ & 30 & 36 & 8,5 & $73-93$ \\
$\begin{array}{c}\text { turbidimetria } \\
\text { Método RCPA B, } \\
\text { nefelometria }\end{array}$ & 30 & 83 & 5,8 & $28-42$ \\
$\begin{array}{c}\text { Método RCPA B, } \\
\text { nefelometria }\end{array}$ & 20 & 35 & 10,5 & $74-95$ \\
\hline
\end{tabular}

*Quando um método instrumentalédeterminado, os dados refletem a variação entre laboratórios dentro do método, ou édada a combinação de variação entre laboratórioe método.

**Abreviaturas como na Tabela 3.

é mais difícil de ser definida para urina porque a matriz é altamente variável em diferentes condições patológicas e a quantificação não é bem definida. Um material de referência que usa albumina altamente purificada pode não refletir as diferentes formas moleculares presentes na urina típica. No entanto, o uso de albumina purificada em um MR pode ser a estratégia mais prática para atingir a calibração padronizada de procedimentos de dosagem de rotina.

\section{Materiais e métodos atualmente utilizados como referência para calibração de procedimentos de dosagem de albumina na urina}

Como atualmente não existem MRs de albumina na urina, a maioria dos métodos de rotina é calibrada para ser rastreável para CRM470 diluído (agora chamado ERMDA470; Institute for Reference Materials and Measurements, Geel, Bélgica), um MR de proteínas séricas de ordem superior com concentração de albumina de 39,7 g//(6). Não foram publicados acordos para os protocolos de diluição para a preparação de concentrações de CRM470 adequadas para calibração do método para urina. A concentração de albumina no CRM470 foi, inicialmente, baseada em um MR para proteínas séricas antigo, USNRP $12-0575 C^{(95)}$. No entanto, ainda não foram elucidados: a estrutura da proteína, as propriedades físico-químicas e o procedimento para a atribuição de valor para USNRP $12-0575 C^{(6)}$. O Grupo de Trabalho IFCC tentou delinear um material de referência semelhante para proteínas urinárias incluindo albumina, mas não conseguiu ${ }^{(93)}$.

Pesquisadores japoneses relataram que $5 \%$ a $10 \%$ dos calibradores utilizados com imunoensaios de rotina continham albumina polimerizada ${ }^{(114)}$. O mesmo estudo revelou que alguns métodos usaram CRM470 diluído como base para a calibração do valor atribuído, enquanto outros utilizaram o coeficiente de absorção molar de albumina sérica humana.

\section{Material de referência candidato para albumina na urina}

A Japanese Society of Clinical Chemistry e o Japanese Comittee for Clinical Laboratory Standards coordenaram o desenvolvimento de um novo MR secundário como candidato para albumina na urina com uma estrutura proteica e propriedades físico-químicas bem definidas ${ }^{(58)}$. O MR foi preparado utilizando-se $>97,5 \%$ de albumina sérica humana monomérica pura em uma matriz de $0,5 \mathrm{~mol} / \mathrm{l}$ de $\mathrm{NaCl}, 20 \mathrm{~g} / \mathrm{l}$ de sacarose e $0,5 \mathrm{~g} / \mathrm{l}$ de NaN3 em $20 \mathrm{mmol} / \mathrm{l}$ de fosfato tamponado, $\mathrm{pH} 7,3$. O material liofilizado teve um intervalo de menos de $3 \%$ de diferença, e manteve-se estável por mais de um ano a $5-10^{\circ} \mathrm{C}$ e $20 \mathrm{~h}$ após a reconstituição com água, tanto a $10^{\circ} \mathrm{C}$ quanto a $25^{\circ} \mathrm{C}$.

Como não há PDR disponível para albumina na urina, o valor do MR candidato foi atribuído à rastreabilidade para CRM470 diluído pela utilização de procedimentos de imunoensaios de rotina ${ }^{(58)}$. Em resumo, 13 sistemas de 
dosagem de rotina participantes tinham reações imunoquímicas idênticas ao MR candidato e ao CRM470 diluído. As concentrações determinadas para o MR candidato por cada valor do método de rotina transferido do CRM470 foram calculadas para atribuir uma concentração para o MR candidato de 226,1 $(8,4) \mathrm{mg} / \mathrm{l}$ (média [incerteza]) após a reconstituição com $3 \mathrm{ml}$ de água.

O objetivo dos investigadores japoneses foi validar a permutabilidade para o novo MR candidato e apresentá-lo ao JCTLM para aprovação. Eles também estão investigando o uso de albumina humana recombinante para desenvolver um material de referência primário baseado na tecnologia utilizada para o candidato a MR secundário.

\section{Candidato a procedimento de referência para a dosagem de albumina na urina}

Um PDR para albumina na urina deve medir especificamente a(s) molécula(s) de albumina na urina original. Devido à heterogeneidade das formas moleculares da albumina na urina, a mensuração não é clara e deve ser definida. Procedimentos imunológicos não são adequados como os PDRs, porque anticorpos em diferentes ensaios podem reagir com diferentes epítopos na molécula de albumina ou nos fragmentos moleculares, e diferentes princípios de dosagens podem dar respostas diferentes.

Pesquisadores da Clínica Mayo, em Rochester, desenvolveram recentemente um procedimento de dosagem por cromatografia líquida-espectrometria de massas (LC-MS), que mede o fragmento $\mathrm{N}$-terminal com 24 aminoácidos da albumina. O método emprega fragmentação induzida destinada a sanar a necessidade de digestão de tripsina e potenciais problemas de digestão incompleta. Resultados similares foram obtidos usando-se albumina humana sérica marcada com ${ }^{15} \mathrm{~N}$, preparada em um sistema de expressão por leveduras ${ }^{(104)}$ ou, menos cara, albumina sérica bovina ${ }^{(4)}$ como padrões internos. A calibração foi baseada em uma urina purificada com carvão e suplementada com albumina sérica humana comercial, cuja concentração foi quantificada pela absortividade molar [38553 I/(mol-cm)] a $280 \mathrm{~nm}^{(42)}$.

Como o procedimento quantifica um fragmento específico da albumina na urina, será necessário investigar em que medida de albumina normal e patológica na urina contém fragmentos com estes 24 aminoácidos ou moléculas de albumina truncadas no N-terminal. A utilização de LC-MS para detectar outros fragmentos de albumina poderia facilitar o estudo da natureza, quantidade e relevância clínica das espécies de albumina urinária nas doenças renais e cardiovasculares. A tecnologia LC-MS não é uma técnica baseada em anticorpos que pode ser desenvolvida em um PDR candidato para albumina na urina.

\section{Sistema de referência para dosagens de creatinina na urina}

A determinação da RAC se baseia tanto em dosagens albumina quanto de creatinina na urina. A variabilidade dos valores RAC calculados refletirá os erros sistemáticos combinados e imprecisões de dosagem de ambos os analitos. É necessária a padronização das dosagens de albumina e de creatinina na urina para obter comparabilidade dos valores obtidos da RAC com diferentes métodos e em diferentes locais.

O programa de padronização iniciado pelo National Kidney Disease Education Program (NKDEP) para a creatinina sérica foi embasado na existência de procedimentos de referência de dosagem validados e no desenvolvimento de um MR secundário, comparável para a creatinina sérica. Um esforço semelhante é necessário para promover dosagens de rotina de alta qualidade de creatinina na urina. $O$ JCTLM listou um procedimento de dosagem de referência para creatinina na urina com base na diluição isotópicacromatografia gasosa-espectrometria de massas ${ }^{(103)}$ e em um MR primariamente certificado (ou seja, substância pura) de creatinina (National Institute for Standards and Technology, EUA, SRM 914a). No entanto, atualmente, não há RMs baseados em matriz derivada disponíveis para creatinina na urina.

Devido à falta de MRs secundários certificados para creatinina na urina, a calibração dos métodos de rotina de dosagem na urina é feita à base de RMs séricos. Esta prática não é a ideal, principalmente devido às importantes diferenças entre as matrizes de urina e o soro.

\section{Conclusão}

Muitas questões exigem esclarecimentos para melhorar a utilização de albumina na urina para avaliação de doença renal. Os dados existentes não sustentam fortes conclusões ou recomendações práticas neste momento. Outras investigações são necessárias para obter informações e evidências objetivas para permitir a padronização da dosagem de albumina na urina e diretrizes para a prática clínica com base na dosagem da excreção de albumina urinária. O grupo NKDEP/IFCC pretende desenvolver programas experimentais para adquirir as informações adicionais. 


\section{Práticas atuais que refletem os pareceres consensuais dos participantes da conferência}

1. O uso do termo "albumina na urina" é recomendado; "microalbumina" é desencorajado.

2. A primeira amostra de urina da manhã proporciona menor variabilidade do que amostras aleatórias.

3. A segunda amostra de urina da manhã também pode ser aceitável, mas não há evidências para apoiar esta prática como superior à primeira urina da manhã.

4. A albumina deve ser dosada na urina que não tenha sido congelada. A albumina na urina é suficientemente estável quando armazenada a $2-8^{\circ} \mathrm{C}$, durante sete dias antes da dosagem. Qualquer turbidez devido a precipitação ou componentes celulares deve ser removida por centrifugação antes do armazenamento refrigerado.

5. Urina refrigerada deve ser aquecida à temperatura ambiente antes de dosagem para dissolver precipitados que tenham se formado e adsorvido a albumina. A urina deve ser examinada visualmente em busca de precipitados e centrifugada, se necessário, para remover precipitado residual.

6. Se a urina for congelada antes da dosagem, deverá ser congelada a $-70^{\circ} \mathrm{C}$ ou menos. Qualquer turbidez devido a precipitação ou componentes celulares deve ser removida por centrifugação antes do armazenamento. Amostras descongeladas devem ser aquecidas à temperatura ambiente e cuidadosamente misturadas antes da dosagem. $O$ efeito do congelamento e descongelamento sobre as formas moleculares da albumina não está completamente compreendido.

7. A relação albumina/creatinina deve ser referida em todas as dosagens de albumina na urina.

8. A confusão surge a partir dos relatórios nos quais os resultados são expressos em diferentes unidades: "mg albumina/mmol de creatinina", "g albumina/mol creatinina", "mg albumina/g creatinina" ou "microgramas albumina/mg de creatinina". Essa situação reflete preferências nacionais ou regionais e parece que não será resolvida. De forma ideal, deveria ser adotado o Sistema Internacional de Unidades. Por outro lado, diretrizes uniformes devem ser sugeridas dentro de um país ou uma região.

9. As concentrações de albumina relatadas em miligramas por litro são difíceis de interpretar e concentrações nestas unidades não devem ser os únicos valores reportados.

\section{Questões que exigem pesquisa mais aprofundada para padronização da dosagem e do relato de albumina na urina}

1. Esclarecimento dos requisitos pré-analíticos.

- Influência do tipo de recipiente.

- Influência do horário da coleta (primeira da manhã, segunda do dia, aleatoriamente, $24 \mathrm{~h}$ ) relacionado com a variabilidade biológica.

- Influência de sangue (sangramento menstrual ou urinário), fluido seminal e outros contaminantes fisiológicos da urina.

2. Esclarecimento das formas moleculares de albumina na urina recente, bem como a definição da medida.

3. Esclarecimento do grau de degradação da albumina na urina sob várias condições de armazenamento.

4. Esclarecimento quanto à variação na composição da matriz urinária sobre a qual o procedimento de dosagem de albumina na urina se deve operar.

5. Esclarecimento dos requisitos clínicos para erro total na dosagem de albumina na urina.

6. Desenvolvimento de um procedimento de dosagem de referência.

7. Desenvolvimento de um material de referência secundário para albumina na urina, incluindo a sua validação de permutabilidade e credenciamento pelo JCTLM.

8. Desenvolvimento de um material de referência secundário para creatinina na urina, incluindo a validação de permutabilidade e o credenciamento pelo JCTLM.

9. Identificação de materiais EQAS adequados que permitam que o desempenho de métodos de rotina seja comparado.

10. Padronização dos resultados das dosagens para permitir que os estudos clínicos determinem os melhores limiares de decisão dos TEA e RAC.

11. Diferentes limites de decisão podem ser necessários para tempo de coleta aleatório vs. primeira da manhã ou outros padronizados, devido ao aumento da variabilidade das amostras coletadas aleatoriamente.

12. A RAC varia com idade, sexo e etnia. A decisão limiar adequada para estes subgrupos necessita de uma investigação mais aprofundada. Um único limiar de decisão não pode ser suficientemente sensível para cada subgrupo.

13. Risco de doença renal crônica e doenças cardiovasculares são funções contínuas de concentração de albumina 
na urina. Os limiares adequados para determinadas populações de risco (por exemplo, população geral ou grupos de alto risco, como diabetes, hipertensão ou doença cardiovascular) devem ser determinados.

14. Uma pesquisa da utilidade de equações específicas para idade e sexo para converter a RAC para um valor TEA estimado no qual uma única referência limite seja apropriada.

\section{Agradecimentos}

Os autores agradecem a contribuição dos participantes da conferência de março de 2007 sobre dosagem e relatório da albumina na urina; seus nomes estão listados no Suplemento de Dados, on-line. Agradecemos também a Elisa Gladstone e Nancy Accetta pelo excelente suporte administrativo.

Este artigo foi traduzido com permissão da American Association for Clinical Chemistry (AACC). A AACC não é responsável pela exatidão da tradução. As ideias apresentadas são aquelas dos autores, e não necessariamente aquelas de AACC ou do Jornal. Reeditado de Clin Chem, v. 55, p. 24-38, 2009, com permissão de editor. Copyright ${ }^{\odot}$ original 2009 American Association for Clinical Chemistry, Inc. Quando citar este artigo, por favor, refira a fonte original de publicação no jornal, Clinical Chemistry.

Tradução para o português: Aline Ribeiro Andriolo, CD.

\section{Referências}

1. AAKRE, K. M. et al. Postanalytical external quality assessment of urine albumin in primary health care: an international survey. Clin Chem, v. 54, p. 1630-6, 2008.

2. AHMED-OUAMEUR, A. et al. The effects of drug complexation on the stability and conformation of human serum albumin: protein unfolding. Cell Biochem Biophys, v. 45, p. 203-13, 2006.

3. AMERICAN DIABETES ASSOCIATION POSITION STATEMENT. Standards of medical care in diabetes. Diabetes Care, v. 30, p. S19-21, 2007.

4. BABIC, N. et al. Application of liquid chromatographymass spectrometry technology for early detection of microalbuminuria in patients with kidney disease. Clin Chem, v. 52, p. 2155-7, 2006.

5. BAR-OR, D. et al. The formation and rapid clearance of a truncated albumin species in a critically ill patient. Clin Chim Acta, v. 365, p. 346-9, 2006.

6. BAUDNER, S. et al. The certification of a matrix reference material for immunochemical measurement of 14 human serum proteins. CRM470. BCR Publication 92/92. Brussels: BCR, 1992

7. BERTOLUCI, M. C. et al. Intensity-related exercise albuminuria in insulin dependent diabetic patients. Diabetes Res Clin Pract, v. 19, p. 217-25, 1993.

8. BOND, J. S. et al. Meprin metalloprotease expression and regulation in kidney, intestine, urinary tract infections and cancer. FEBS Lett, v. 579, p. 3317-22, 2005.

9. BRENNAN, S. O.; GEORGE, P. M. Three truncated forms of serum albumin associated with pancreatic pseudocyst. Biochim Biophys Acta, v. 1481, p. 337-43, 2000.

10. BRENNAN, S. O.; GEORGE, P. M.; PEACH, R. J. Characterisation of a slow component of normal human serum albumin. Clin Chim Acta, v. 176, p. 179-84, 1988.

11. BRENNER, B. M.; HOSTETTER, T. H.; HUMES, H. D. Molecular basis of proteinuria of glomerular origin. N Engl J Med, v. 298, p. 826-33, 1978.
12. BRINKMAN, J. W. et al. Apparent loss of urinary albumin during long-term frozen storage: HPLC vs. immunonephelometry. Clin Chem, v. 53, p. 1520-6, 2007.

13. BRINKMAN, J. W. et al. Falsely low urinary albumin concentrations after prolonged frozen storage of urine samples. Clin Chem, v. 51, p. 2181-3, 2005.

14. BRINKMAN, J. W. et al. Which method for quantifying urinary albumin excretion gives what outcome? A comparison of immunonephelometry with HPLC. Kidney Int, v. 66, n. 92S, p. S69-75, 2004.

15. CANDIANO, G. et al. Repetitive fragmentation products of albumin and 1-antitrypsin in glomerular diseases associated with nephritic syndrome. J Am Soc Nephrol, v. 17 , p. $3139-48,2006$

16. CARING FOR AUSTRALIANS WITH RENAL INJURY (CARI) GUIDELINES. Urine protein as a diagnostic test. 2004. Available from: <http//:www.cari. org.au/ckd urineprot_list_pub 2004.php>. Accessed in: nov 2008.

17. CARTER, D. C. et al. Three-dimensional structure of human serum albumin. Science (Wash DC), v. 244, p. 1195-8, 1989.

18. CARTER, J. L. et al. Does urinary tract infection cause proteinuria or microalbuminuria? A systematic review. Nephrol Dial Transplant, v. 21, p. 3031-7, 2006.

19. CHA, T. et al. Renal handling of glycated albumin in noninsulin-dependent diabetes mellitus with nephropathy. Diabet Res Clin Pract, v. 12, p. 149-56, 1991.

20. CHALMERS, M. J. et al. Combined top-down and bottom-up mass spectrometric approach to characterization of biomarkers for renal disease. Anal Chem, v. 77, p. 7163-71, 2005.

21. CHAUDHURY $\mathrm{C}$, et al. The major histocompatibility complex-related $F c$ receptor for IgG (FcRn) binds albumin and prolongs its lifespan. J Exp Med, v. 197, p. 315-22, 2003. 
22. CLARK, D. C.; SMITH, L. J.; WILSON, D. R. A spectroscopic study of the conformational properties of foamed bovine serum albumin. J Colloid Interface Sci, v. 121, p. 136-7, 1988.

23. CLAVANT, S. P. et al. The analysis and characterization of immunounreactive urinary albumin in healthy volunteers. Clin Biochem, v. 39, p. 143-51, 2006.

24. CLERICO, A. et al. Exercise-induced proteinuria in welltrained athletes. Clin Chem, v. 36, p. 562-4, 1990.

25. CURRY, S. et al. Crystal structure of human serum albumin complexed with fatty acid reveals an asymmetric distribution of binding sites. Nature (Lond) Struct Biol, v. 5, p. 827-35, 1998.

26. CUTILLAS, P. R. et al. The urinary proteome in Fanconi syndrome implies specificity in the reabsorption of proteins by renal proximal tubule cells. Am J Physiol Renal Physiol, v. 287, p. F353-64, 2004.

27. DODGE, W. F. et al. Proteinuria and hematuria in schoolchildren: epidemiology and early natural history. J Pediatr, v. 88, p. 327-47, 1976.

28. EDGE, J. A. et al.; Youth and Family Advisory Committee of Diabetes UK. Diabetes services in the UK: fourth national survey; are we meeting NSF standards and NICE guidelines? Arch Dis Child, v. 90, p. 1005-9, 2005.

29. ELVING, L. D. et al. Screening for microalbuminuria in patients with diabetes mellitus: frozen storage of urine decreases their albumin content. Clin Chem, v. 35, p. 308-10, 1989.

30. ESTIVI, P. et al. Urinary protein excretion induced by exercise: effect of a mountain agonistic footrace in healthy subjects: renal function and mountain footrace. J Sports Med Phys Fitness, v. 32, p. 196-200, 1992.

31. FAGNANI F, et al. Management of hypertension and screening of renal complications by GPs in diabetic type 2 patients (France, 2001). Diabetes Metab, v. 29, p. 58-64, 2003.

32. FISKERSTRAND, T. et al. Homocystein e and other thiols in plasma and urine: automated determination and sample stability. Clin Chem, v. 39, p. 263-71, 1993.

33. FOGH-ANDERSEN, N. Albumin/calcium association at different $\mathrm{pH}$, as determined by potentiometry. Clin Chem, v. 23, p. 2122-6, 1977.

34. FOGH-ANDERSEN, N.; BJERRUM, P. J.; SIGGAARDANDERSEN, O. lonic binding, net charge, and Donnan effect of human serum albumin as a function of $\mathrm{pH}$. Clin Chem, v. 39, p. 48-52, 1993.

35. FUJIWARA, S.; AMISAKI, T. Molecular dynamics study of conformational changes in human serum albumin by finding of fatty acids. Proteins, v. 64, p. 730-9, 2006.

36. GARG, S. K. et al. Exercise versus overnight albumin excretion rates in subjects with type 1 diabetes. Diabetes Res Clin Pract, v. 28, p. 51-5, 1995.

37. GEKLE, M. Renal tubule albumin transport. Ann Rev Physiol, v. 67, p. 573-94, 2005.

38. GHIGGERI, G. M. et al. Characterization of cationic albumin in minimal change nephropathy. Kidney Int, v. 32, p. 547-53, 1987.

39 GHIGGERI, G. M. et al. Electrical charge of serum and urinary albumin in normal and diabetic humans. Kidney Int, v. 28, p. 168-77, 1985.
40. GIAMPIETRO, O. et al. How and how long to store urine samples before albumin radioimmunoassay: a practical response. Clin Chem, v. 39, p. 533-6, 1993.

41. GIAMPIETRO, O. et al. Measurement of urinary albumin excretion (UAE) in diabetic patients: immunonephelometry versus radioimmunoassay. J Nucl Med Allied Sci, v. 33, p. 252-7, 1989.

42. GILL, S. C.; VON HIPPEL, P. H. Calculation of protein extinction coefficients from amino acid sequence data. Anal Biochem, v. 182, p. 319-26, 1989.

43. HARA, F.; NAKAZATO, K.; SHIBA, K. Studies of diabetic nephropathy; I, effects of storage time and temperature on microalbuminuria. Biol Pharma Bull, v. 17, p. 1241-5, 1994.

44. HARA, F.; SHIBA, K. Nonspecific binding of urinary albumin on preservation tube. Jpn J Clin Chem, v. 32, Suppl 1, p. 28-9, 2003.

45. HARWELL, T. S. etal. Laboratory testing for microalbuminuria in the general community. Diabetes Care, v. 23, p. 1028-30, 2000.

46. HAUBITZ, M. et al. Urine protein patterns can serve as diagnostic tools in patients with IgA nephropathy. Kidney Int, v. 67, p. 2313-20, 2005.

47. HEINE, G.; RAIDA, M.; FORSSMANN, W. G. Mapping of peptides and protein fragments in human urine using liquid chromatography-mass spectrometry. J Chromatogr A, v. 776, p. 117-24, 1997.

48. HEMMINGSEN, L.; SKAARUP, P. Urinary excretion of ten plasma proteins in patients with febrile diseases. Acta Med Scand, v. 201, p. 359-64, 1977.

49. HERNANDEZ, C.; SIMO, R. Albumin excretion rate is not affected by asym ary peptide measurements. Clin Chem, v. 51, p. 1411-9, 2005.

53. HORTIN, G. L.; SEAM, N.; HOEHN, G. T. Bound homocysteine, cysteine, and cysteinylglycine distribution between albumin and globulins. Clin Chem, v. 52, p. 2258-64, 2006.

54. HORTIN, G. L.; SVIRIDOV, D. Analysis of molecular forms of albumin in urine. Proteomics Clin Appl, v. 2, p. 950-5, 2008.

55. HUTTUNEN, N. P. et al. Exercise-induced proteinuria in children and adolescents. Scand J Clin Lab Invest, v. 4, p. 583-7, 1981.

56. INTERNATIONAL ORGANIZATION FOR STANDARDIZATION. ISO 17511: in vitro diagnostic medical devices: measurement of quantities in biological samples: metrological traceability of values assigned to calibrators and control materials. Geneva, 2003.

57. INTERNATIONAL DIABETES FEDERATION CLINICAL GUIDELINES TASK FORCE. Global guidelines for type 2 diabetes; chapter 14: kidney damage. Available from: <http://www.idf.org/webdata/docs/GGT2D\%2014\%20 Kidney\%20damade.pdf>. Accessed in: nov 2008.

58. ITOH, Y. Standardization of immunoassays for urine albumin. Jpn J Clin Chem, v. 37, p. 5-14, 2008.

59. IWAO, Y. et al. Changes in net charge and alpha-helical content affect the pharmacokinetic properties of human serum albumin. Biochim Biophys Acta, v. 1774, p. 1582-90, 2007.

60. JOINT COMMITTEE FOR TRACEABILITY IN LABORATORY MEDICINE (JCTLM). Database of higher-order reference 
materials, measurement methods/procedures and services. Available from: <http://www.bipm.org/ jctlm>. Accessed in: nov. 2008.

61. JOINT SPECIALTY COMMITTEE ON RENAL MEDICINE OF THE ROYAL COLLEGE OF PHYSICIANS AND THE RENAL ASSOCIATION AND THE ROYAL COLLEGE OF GENERAL PRACTITIONERS. Chronic kidney disease in adults: UK guidelines for identification, management and referral. London: Royal College of Physicians, 2006. $112 \mathrm{p}$.

62. JONES, G. Urine albumin sampling and reporting: current practice in Australasia. Clin Biochem Newsl, p. 31-3, 2006.

63. JURGENS, M. etal. Towards characterization of the human urinary peptidome. Comb Chem High Throughput Screen, v. 8, p. 757-65, 2005.

64. KAUSLER, E.; SPITELLER, G. Fragments from albumin and 2-microglobulin: constituents of the middle molecule fraction in hemofiltrate. Biol Chem Hoppe-Seyler, v. 372, p. 849-55, 1991.

65. KEMPERMAN, R. F. et al. Comparative urine analysis by liquid chromatographymass spectrometry and multivariate statistics: method development, evaluation, and application to proteinuria. J Proteome Res, v. 6 , p. 194-206, 2007.

66. KHAN, A.; PACKER, N. H. Simple urinary sample preparation for proteomic analysis. J Proteome Res, v. 5, p. 2824-38, 2006.

67. KRAGH-HANSEN, U.; CHUANG, V. T.; OTAGIRI, M. Practical aspects of the ligand-binding and enzymatic properties of human serum albumin. Biol Pharm Bull, v. 25, p. 695-704, 2002.

68. LAD, M. D. et al. The adsorbed conformation of globular proteins at the air/water interface. Phys Chem Chem Phys, v. 8, p. 2179-86, 2006

69. LAFITTE, D. et al. Optimized preparation of urine samples for two-dimensional electrophoresis and initial application to patient samples. Clin Biochem, v. 35, p. 581-9, 2002.

70. LEVEY, A. S. et al. Definition and classification of chronic kidney disease: a position statement from kidney disease: improving global outcomes (KDIGO). Kidney Int, v. 67, p. 2089-100, 2005.

71. LINKSDE JONG, P. E.; CURHAN, G. C. Screening, monitoring, and treatment of albuminuria: public health perspectives. J Am Soc Nephrol, v. 17, p. 2120-6, 2006.

72. LOPEZ, M. F. et al. A novel, highthroughput workflow for discovery and identification of serum carrier proteinbound peptide biomarker candidates in ovarian cancer samples. Clin Chem, v. 53, p. 1067-74, 2007

73. LOWENTHAL, M. S. et al. Analysis of albumin-associated peptides and proteins from ovarian cancer patients. Clin Chem, v. 51, p. 1933-45, 2005.

74. MACNEIL, M. L. W. et al. Considerations when measuring urinary albumin: precision, substances that may interfere, and conditions for sample storage. Clin Chem, v. 37, p. 2120-3, 1991.

75. MERLER, E. et al. Differences between urinary albumin and serum albumin. Nature(Lond), v. 196, p. 1207-8, 1962.

76. MURA-GALELLI, M. J. et al. Adsorption/desorption of human serum albumin on hydroxyapatite: a critical analysis of the Langmuir model. Proc Natl Acad Sci USA, v. 88, p. 5557-61, 1991.

77. MUSANTE, L. etal. Active focal segmental glomerulosclerosis is associated with massive oxidation of plasma albumin. J Am Soc Nephrol, v. 18, p. 799-810, 2007.

78. NATIONAL INSTITUTE FOR CLINICAL EXCELLENCE. Management of type 2 diabetes: renal disease, prevention and early management (Guideline F); 2002. (Derived from the guideline entitled Diabetic renal disease: prevention and early management commissioned from collaboration between the Royal College of General Practitioners, the Royal College of Physicians, and the Royal College of Nursing and Diabetes UK.) Available from: <http://www.nice.org.uk/ Guidance/F>. Accessed in: nov. 2008.

79. NATIONAL KIDNEY FOUNDATION. Kidney disease outcomes quality improvement (K/DOQI $\left.{ }^{\mathrm{TM}}\right)$ clinical practice guidelines on hypertension and antihypertensive agents in chronic kidney disease. Am J Kidney Dis, v. 43 , p. S1-290, 2004

80. NATIONAL KIDNEY FOUNDATION. Kidney disease outcomes quality improvement $\left(\mathrm{K} / \mathrm{DOQ} \mathrm{I}^{\mathrm{TM}}\right)$ clinical practice guidelines for chronic kidney disease: evaluation, classification and stratification. Am J Kidney Dis, v. 39, p. S1-266, 2002

81. NATIONAL KIDNEY FOUNDATION. Kidney disease outcomes quality improvement (K/DOQI ${ }^{\mathrm{TM}}$ ) clinical practice guidelines and clinical practice recommendations for diabetes and chronic kidney disease. Am J Kidney Dis, v. 49, p. S1-180, 2007.

82. NICHOLOV, R. et al. Human serum albumin adsorption at solid-liquid interface monitored by electron spin resonance spectroscopy. In: HORBETT, T. A.; BRASH, J. L. (eds.). Proteins at interfaces II: fundamentals and applications. Washington (DC): American Chemical Society, 1995. p 280-95. (ACS Symposium Series, 0097-6165; 602)

83. NORDEN, A. G. et al. Glomerular protein sieving and implications for renal failure in Fanconi syndrome. Kidney Int, v. 60, p. 1885-92, 2001.

84. NORDEN, A. G. W. et al. Quantitative amino acid and proteomic analysis: very low excretion of polypeptides 750 Da in normal urine. Kidney Int, v. 66, 1994-2003, 2004.

85. O'BRIEN, S. F. et al. Exercise testing as a long-term predictor of the development of microalbuminuria in normoalbuminuric IDDM patients. Diabetes Care, v. 18, p. 1602-5, 1995.

86. OETTL, K.; STAUBER, R. E. Physiological and pathological changes in the redox state of albumin critically influence its binding properties. Br J Pharmacol, v. 151, p. 580-90, 2007

87. OSBERG, I. et al. Effects of storage time and temperature on measurement of small concentrations of albumin in urine. Clin Chem, v. 36, p. 1428-30, 1990.

88. OSICKA, T. M.; COMPER, W. D. Characterization of immunochemically nonreactive urinary albumin. Clin Chem, v. 50, p. 2286-91, 2004.

89. OWEN, W. E.; ROBERTS, W. L. Performance characteristics of an HPLC assay for urinary albumin. Am J Clin Pathol, v. 124, p. 219-25, 2005. 
90. PETERS, T. All about albumin: biochemistry, genetics, and medical applications. San Diego (CA): Academic Press, 1996. 432 p.

91. POORTMANS, J. R.; OUCHINSKY, M. Glomerular filtration rate and albumin excretion after maximal exercise in aging sedentary and active men. J Gerontol A Biol Sci Med Sci, v. 61, p. 1181-5, 2006.

92. POORTMANS, J.; DORCHY, H.; TOUSSAINT, D. Urinary excretion of total proteins, albumin, and beta 2-microglobulin during rest and exercise in diabetic adolescents with and without retinopathy. Diabetes Care, v. 5, p. 617-23,1982.

93. PRICE, C. P. et al. First international reference preparation for individual proteins in urine. Clin Biochem, v. 31, p. 467-74, 1998.

94. RAIDA, M. et al. Liquid chromatography and electrospray mass spectrometric mapping of peptides from human plasma filtrate. J Am Soc Mass Spectrom, v. 10, p. 45-54, 1999.

95. REIMER, C. B. et al. Collaborative calibration of the US National and the College of American Pathologists reference preparations for specific serum proteins. Am J Clin Pathol, v. 77, p. 12-9, 1982.

96. RICHMOND, J. M. et al. Patterns of urinary protein excretion in patients with sepsis. Nephron, v. 31, p. 219-23, 1982.

97. RICHTER, R. et al. Composition of the peptide fraction in human blood plasma: database of circulating human peptides. J. Chromatogr B, v. 726, p. 25-35, 1999.

98. ROBERTSHAW, M. et al. Protein excretion after prolonged exercise. Ann Clin Biochem, v. 30, Pt 1, p. 34-7, 1993.

99. RUSSO, L. M.; BAKRIS, G. L.; COMPER, W. D. Renal handling of albumin: a critical review of basic concepts and perspective. Am J Kidney Dis, v. 39, p. 899-919, 2002.

100. RYTAND, D. A.; SPREITER, S. Prognosis in postural (orthostatic) proteinuria: forty to fifty-year follow-up of six patients after diagnosis by Thomas Addis. N Eng/ J Med, v. 305, p. 618-21, 1981.

101. SAKATA, S.; ATASSI, M. Z. Immunochemistry of serum albumin, $X$ : five major antigenic sites of human serum albumin are extrapolated from bovine albumin and confirmed by synthetic peptides. Mol Immunol, v. 17, p. 139-42, 1980.

102. SENTURK, U. K. et al. Biphasic pattern of exerciseinduced proteinuria in sedentary and trained men. Nephron Physiol, v. 105, p. 22-32, 2007.

103. SIEKMANN, L. Determination of creatinine in human serum by isotope dilution-mass spectrometry:definitive methods in clinical chemistry, IV. J Clin Chem Clin Biochem, v. 23, p. 137-44, 1985.

104. SINGH, R. et al. A liquid chromatographymass spectrometry method for the quantification of urinary albumin using a novel 15 Nisotopically labeled albumin internal standard. Clin Chem, v. 53, p. 540-2, 2007.

105. SOLLING, J.; SOLLING, K.; MOGENSEN, C. E. Patterns of proteinuria and circulating immune complexes in febrile patients. Acta Med Scand, v. 212, p. 167-9, 1982.

106. SPRINGBERG, P. D. et al. Fixed and reproducible orthostatic proteinuria: results of a 20-year follow-up study. Ann Intern Med, v. 97, p. 516-9, 1982.
107. SUDLOW, G.; BIRKETT, D. J.; WADE, D. N. Further characterization of specific drug binding sites on human serum albumin. Mol Pharmacol, v. 12, p. 1052-61, 1976.

108. SVIRIDOV, D. et al. Co-elution of other proteins with albumin during size-exclusion HPLC: implications for urine albumin analysis. Clin Chem, v. 52, p. 389-97, 2006.

109. SVIRIDOV, D.; DRAKE, S. K.; HORTIN, G. L. Reactivity of urinary albumin (microalbumin) assays with fragmented or modified albumin. Clin Chem, v. 54, p. 61-8, 2008.

110. TAAL, M.; TOMSON, C. Clinical practice guidelines: module 1: chronic kidney disease. 2. ed., final version. Petersfield (UK): The Renal Association, 2007. Available from: <http://www.renal.org/guidelines/module1.html>. Accessed in: dec. 2008.

111. TENCER, J. et al. Long-term stability of albumin, protein $\mathrm{HC}$, immunoglobulin G, Kappa- and lambda-chainimmunoreactivity, orosomucoid, and alpha 1-antitrypsin in urine stored at 20 degrees C. Scand J Urol Nephrol, v. 31, p. 67-71, 1997.

112. THONGBOONKERD, V. Proteomic analysis of normal urinary proteins isolated by acetone precipitation or ultracentrifugation. Kidney Int, v. 62, p. 1461-9, 2002.

113. TROF, R. J. et al. Biomarkers of acute renal injury and renal failure. Shock, v. 26, p. 245-53, 2006.

114. UEMURA, Y. Preparation of reference material for albumin without lot difference. Laboratory Med, v. 5, p. 557-61, 2004.

115. VARGHESE, S. A. et al. Urine biomarkers predict the cause of glomerular disease. J Am Soc Nephrol, v. 18, p. 913-22, 2007.

116. VEHASKARI, V. M.; RAPOLA, J. Isolated proteinuria: analysis of a school-age population. J Pediatr, v. 101, p. 661-8, 1982.

117. VITTINGHUS, E.; MOGENSEN, C. E. Graded exercise and protein excretion in diabetic man and the effect of insulin treatment. Kidney Int, v. 21, p. 725-9, 1982.

118. VLASKOU, D. et al. Human neutral brush border endopeptidase EC 3.4.24.11 in urine, its isolation, characterization and activity in renal disease. Clin Chim Acta, v. 297, p. 103-21, 2000.

119. WAGNER, M. G. et al. Epidemiology of proteinuria: a study of 4,807 schoolchildren. J Pediatr, v. 73, p. 825-32, 1968.

120. WAGNER, Z. et al. Serum carboxymethyllysine predicts mortality in hemodialysis patients. Am J Kidney Dis, v. 47, p. 294-300, 2006.

121. WATTS, G. F.; O'BRIEN, S. F.; SHAW, K. M. Urinary infection and albumin excretion in insulin-dependent diabetes mellitus: implications for the measurement of microalbuminuria. Diabet Med, v. 13, p. 520-4, 1996.

122. WATTS, G. F.; SHAW, K. M.; POLAK, A. The use of random urine samples to screen for microalbuminuria in the diabetic clinic. Practical Diabetes, v. 3, p. 86-8, 1986.

123. WESTWOOD, M. E.; THORNALLEY, P. J. Molecular characteristics of methylglyoxal-modified bovine and human serum albumins: comparison with glucose-derived advanced glycation endproductmodified serum albumins. J Protein Chem, v. 14, p. 359-72, 1995. 
124. WIGGINS, R. C. et al. Fragmentation and polymeric complexes of albumin in human urine. Clin Chim Acta, v. 149 , p. $155-63,1985$

125. WITTE, E. C. et al. Timed urine collections or spot urine samples to monitor albuminuria over time [Abstract]? J Am Soc Nephrol, v. 18, p. 337A, 2007.

126. WITTKE, S et al. Discovery of biomarkers in human urine and cerebrospinal fluid by capillary electrophoresis coupled to mass spectrometry: towards new diagnostic and therapeutic approaches. Electrophoresis, v. 26, p. 1476-87, 2005.

127. YAGAME, M. et al. Urinary albumin fragments as a new clinical parameter for the early detection of diabetic nephropathy. Intern Med, v. 34, p. 463-8, 1995.

128. ZEREFOS, P. G. et al. Characterization of the human urine proteome by preparative electrophoresis in combination with 2-DE. Proteomics, v. 6, p. 4346-55, 2006. 